Correspondence

Jung-Hoon Yoon

jhyoon69@skku.edu

\section{Thalassomonas agariperforans sp. nov., an agarolytic bacterium isolated from marine sand}

\author{
Sooyeon Park, ${ }^{1}$ Won-Chan Choi, ${ }^{1}$ Tae-Kwang Oh ${ }^{1}$ and Jung-Hoon Yoon ${ }^{1,2}$
}

\author{
${ }^{1}$ Korea Research Institute of Bioscience and Biotechnology (KRIBB), PO Box 115, Yusong, Taejon, \\ Republic of Korea \\ ${ }^{2}$ Department of Food Science and Biotechnology, Sungkyunkwan University, Jangan-gu, Suwon, \\ Republic of Korea
}

\begin{abstract}
A Gram-staining-negative, motile, agarolytic bacterium, designated $\mathrm{M}-\mathrm{M} 1^{\top}$, was isolated from marine sand obtained from Geoje Island, South Sea, Korea, and its taxonomic position was investigated using a polyphasic taxonomic approach. Strain $\mathrm{M}-\mathrm{M} 1^{\top}$ grew optimally at $\mathrm{pH} 7.0-8.0$, at $30{ }^{\circ} \mathrm{C}$ and in the presence of $2 \%(\mathrm{w} / \mathrm{v}) \mathrm{NaCl}$. It did not grow in the presence of $>7 \%(\mathrm{w} / \mathrm{v}) \mathrm{NaCl}$. Phylogenetic analysis based on $16 \mathrm{~S}$ rRNA gene sequences showed that strain $\mathrm{M}-\mathrm{M} 1^{\top}$ fell within the clade comprising members of the genus Thalassomonas, clustering with Thalassomonas agarivorans $\mathrm{TMA}^{\top}$, Thalassomonas loyana CBMAI $722^{\top}$ and Thalassomonas ganghwensis JC2041 ${ }^{\top}$, with which it exhibited 16S rRNA gene sequence similarity values of 96.4, 96.0 and $94.9 \%$ respectively. Strain $\mathrm{M}-\mathrm{M} 1^{\top}$ exhibited $94.7-95.2 \% 16 \mathrm{~S}$ rRNA gene sequence similarity to the other species of the genus Thalassomonas. Strain $\mathrm{M}-\mathrm{M} 1^{\top}$ contained $\mathrm{Q}-8$ as the predominant ubiquinone and $\mathrm{C}_{16: 1} \omega 7 \mathrm{c}$ and/or iso- $\mathrm{C}_{15: 0} 2-\mathrm{OH}, \mathrm{C}_{16: 0}$ and $\mathrm{C}_{18: 1} \omega 7 \mathrm{c}$ as the major fatty acids. The DNA G + C content was 44.2 mol\%. Strain $M-M 1^{\top}$ could be differentiated from phylogenetically related species of the genus Thalassomonas by differences in some phenotypic properties. On the basis of the phenotypic, chemotaxonomic and phylogenetic data, strain $\mathrm{M}-\mathrm{M} 1^{\top}$ is considered to represent a novel species of the genus Thalassomonas, for which the name Thalassomonas

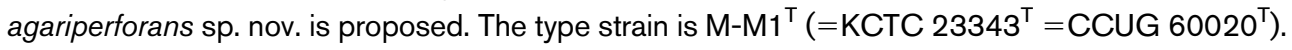

The genus Thalassomonas belongs to the order Alteromonadales (Bowman \& McMeekin, 2005) in the class Gammaproteobacteria and was first proposed by Macián et al. (2001). At the time of writing, the genus Thalassomonas consists of six species with validly published names: Thalassomonas viridans (Macián et al., 2001), Thalassomonas ganghwensis (Yi et al., 2004), Thalassomonas loyana (Thompson et al., 2006), Thalassomonas agarivorans (Jean et al., 2006) and Thalassomonas actiniarum and Thalassomonas haliotis (Hosoya et al., 2009). In this study, an agarolytic bacterial strain, $\mathrm{M}-\mathrm{M} 1^{\mathrm{T}}$, which was isolated from marine sand of Geoje island in the South Sea, Korea, is described. Comparative 16S rRNA gene sequence analysis indicated that strain $\mathrm{M}-\mathrm{M} 1^{\mathrm{T}}$ is most phylogenetically affiliated to the genus Thalassomonas. The aim of the present work was to determine the exact taxonomic position of strain $\mathrm{M}-\mathrm{M} 1^{\mathrm{T}}$ by using a polyphasic characterization that included the determination of phenotypic properties and a detailed phylogenetic investigation based on 16S rRNA gene sequences.

Strain $\mathrm{M}-\mathrm{M} 1^{\mathrm{T}}$ was isolated by the dilution plating technique on marine agar 2216 (MA; Difco) at $25^{\circ} \mathrm{C}$. The type strains

The GenBank/EMBL/DDBJ accession number for the 16S rRNA gene sequence of strain $\mathrm{M}-\mathrm{M} 1^{\top}$ is $\mathrm{HM} 237288$. of three species of the genus Thalassomonas were used as reference strains for phenotypic characterization and fatty acid analysis: T. agarivorans JCM $13379^{\mathrm{T}}$ was obtained from the Japan Collection of Microorganisms, Saitama, Japan; $T$. loyana $\mathrm{LMG} 22536^{\mathrm{T}}$ was obtained from the Laboratorium voor Microbiologie, Universiteit Gent, Belgium; and $T$. ganghwensis KCTC $12041^{\mathrm{T}}$ was obtained from the Korean Collection for Type Cultures, Taejon, Korea. The morphological, physiological and biochemical characteristics of strain $\mathrm{M}-\mathrm{M} 1^{\mathrm{T}}$ were investigated by using routine cultivation on MA at $30{ }^{\circ} \mathrm{C}$. Cell morphology was examined by using light microscopy (Nikon E600) and transmission electron microscopy (CM-20; Philips). Flagellation was determined by using transmission electron microscopy on cells from an exponentially growing culture. For this purpose, the cells were negatively stained with $1 \%(\mathrm{w} / \mathrm{v})$ phosphotungstic acid and the grids were examined after being air-dried. The Gram reaction was determined by using the bioMérieux Gram stain kit according to the manufacturer's instructions. Growth at various temperatures $(4,10,25,30,37,40$ and $45{ }^{\circ} \mathrm{C}$ ) was measured on MA. Growth in the absence of $\mathrm{NaCl}$ and in the presence of 0.5 and $1.0 \%(\mathrm{w} / \mathrm{v}) \mathrm{NaCl}$ was investigated by using trypticase soy broth prepared according to the formula of the Difco medium except that $\mathrm{NaCl}$ was excluded and $0.45 \%(\mathrm{w} / \mathrm{v}) \mathrm{MgCl}_{2} \cdot 6 \mathrm{H}_{2} \mathrm{O}$ or $0.06 \%$ 
(w/v) $\mathrm{KCl}$ was added. Growth at various $\mathrm{NaCl}$ concentrations $(2.0-15.0 \%, \mathrm{w} / \mathrm{v}$, in increments of $1.0 \%)$ was investigated in marine broth 2216 (MB; Difco). The $\mathrm{pH}$ range for growth was determined in $\mathrm{MB}$ adjusted to $\mathrm{pH}$ 4.59.5 (in increments of $0.5 \mathrm{pH}$ units) by the addition of $\mathrm{HCl}$ or $\mathrm{Na}_{2} \mathrm{CO}_{3}$. Growth under anaerobic conditions was determined after incubation in a Forma anaerobic chamber on MA and on MA supplemented with $0.1 \%(\mathrm{w} / \mathrm{v})$ potassium nitrate, both of which had been prepared anaerobically under nitrogen atmosphere. Catalase and oxidase activities were determined as described by Cowan \& Steel (1965). Hydrolysis of agar, casein, starch, hypoxanthine, xanthine and tyrosine was performed on MA, using the substrate concentrations described by Cowan \& Steel (1965). Hydrolysis of aesculin, gelatin, Tweens (20, 40, 60 and 80) and urea, and nitrate reduction were investigated as described by Lanyi (1987) with the modification that artificial seawater (containing $23.6 \mathrm{~g} \mathrm{NaCl}, 0.64 \mathrm{~g} \mathrm{KCl}$, $4.53 \mathrm{~g} \mathrm{MgCl}_{2} \cdot 6 \mathrm{H}_{2} \mathrm{O}$, $5.94 \mathrm{~g} \mathrm{MgSO}_{4} \cdot 7 \mathrm{H}_{2} \mathrm{O}$ and $1.3 \mathrm{~g}$ $\mathrm{CaCl}_{2} .2 \mathrm{H}_{2} \mathrm{O}$ per litre of distilled water; Bruns et al., 2001) was used for preparation of media. Cellulase and xylanase activities were investigated on MA containing $0.5 \%$ carboxymethylcellulose (Sigma) and xylan (Sigma), respectively, and detected according to the method of Teather \& Wood (1982). DNase activity was examined by using DNase test agar with methyl green (Difco) with the modification that artificial seawater was used for the preparation of media. $\mathrm{H}_{2} \mathrm{~S}$ production was tested as described by Bruns et al. (2001). Utilization of substrates as sole carbon and energy sources was tested as described by Baumann \& Baumann (1981), using supplementation with $2 \%$ (v/v) Hutner's mineral base (Cohen-Bazire et al., 1957) and $1 \%(\mathrm{v} / \mathrm{v})$ vitamin solution (Staley, 1968). Susceptibility to antibiotics was investigated on MA plates by using antibiotic discs containing the following: polymyxin B, $100 \mathrm{U}$; streptomycin, $50 \mu \mathrm{g}$; penicillin $\mathrm{G}, 20 \mathrm{U}$; chloramphenicol, $100 \mu \mathrm{g}$; ampicillin, $10 \mu \mathrm{g}$; cephalothin, $30 \mu \mathrm{g}$; gentamicin, $30 \mu \mathrm{g}$; novobiocin, $5 \mu \mathrm{g}$; tetracycline, $30 \mu \mathrm{g}$; kanamycin, $30 \mu \mathrm{g}$; lincomycin, $15 \mu \mathrm{g}$; oleandomycin, $15 \mu \mathrm{g}$; neomycin, $30 \mu \mathrm{g}$; and carbenicillin, $100 \mu \mathrm{g}$. Other physiological and biochemical tests were performed using the API 20E and API ZYM systems (bioMérieux) incubated at $30{ }^{\circ} \mathrm{C}$ according to the instructions of the manufacturer.

Cell biomass of strain $\mathrm{M}-\mathrm{M} 1^{\mathrm{T}}$ for DNA extraction and for isoprenoid quinone analysis was obtained from cultures grown in $\mathrm{MB}$ at $30^{\circ} \mathrm{C}$. Chromosomal DNA was extracted and purified according to the method described by Yoon et al. (1996), with the modification that RNase T1 was used in combination with RNase A to minimize contamination by RNA. 16S rRNA gene amplification was performed using two universal primers as described previously (Yoon et al., 1998) and the PCR products were purified by using a QIAquick PCR purification kit (Qiagen). Sequencing of the amplified $16 \mathrm{~S}$ rRNA gene and phylogenetic analysis were performed as described by Yoon et al. (2003). Isoprenoid quinones were analysed as described by Komagata \& Suzuki (1987), using reversed-phase HPLC and a YMC ODS-A $(250 \times 4.6 \mathrm{~mm})$
Table 1. Differential phenotypic characteristics of strain $M-$ $\mathrm{M} 1^{\top}$ and the type strains of phylogenetically related species of the genus Thalassomonas

Strains: 1, Thalassomonas agariperforans sp. nov. M-M1 ${ }^{\mathrm{T}} ; 2, T$. agarivorans JCM $13379^{\mathrm{T}}$; 3, T. ganghwensis KCTC $12041^{\mathrm{T}}$; 4, T. loyana LMG $22536^{\mathrm{T}}$. All data from this study except for $\mathrm{NaCl}$ range for growth, growth at 10 and $40{ }^{\circ} \mathrm{C}$, catalase, oxidase, nitrate reduction and hydrolysis of aesculin, agar, DNA, gelatin, starch and urea; these data from Yi et al. (2004), Jean et al. (2006) and Thompson et al. (2006). +, Positive; -, negative; w, weak. All strains are Gram-negative and positive for catalase and nitrate reduction (weak for T. loyana), hydrolysis of aesculin, DNA and Tweens 20, 40, 60 and 80, utilization of D-galactose, D-glucose and maltose, activity of alkaline phosphatase, leucine arylamidase and naphthol-AS-BI-phosphohydrolase (weak for T. agarivorans and T. loyana) and susceptibility to streptomycin, novobiocin, neomycin, gentamicin, carbenicillin, polymyxin $B$ and chloramphenicol. All strains are negative for production of indole and $\mathrm{H}_{2} \mathrm{~S}$, hydrolysis of urea, xanthine and hypoxanthine, utilization of Larabinose, trehalose, benzoate, citrate, formate, L-malate, succinate and L-glutamate, activity of arginine dihydrolase, lysine decarboxylase and ornithine decarboxylase, lipase (C14), valine arylamidase, cystine arylamidase, trypsin, $\alpha$-chymotrypsin, $\alpha$-galactosidase, $\beta$-galactosidase, $\beta$-glucuronidase, $\alpha$-glucosidase, $\beta$-glucosidase, $\alpha$-mannosidase and $\alpha$ fucosidase and susceptibility to lincomycin and penicillin $\mathrm{G}$.

\begin{tabular}{|c|c|c|c|c|}
\hline Characteristic & 1 & 2 & 3 & 4 \\
\hline $\mathrm{NaCl}$ range for growth (\%) & $0-6$ & $1-5$ & $1-8$ & $1-9$ \\
\hline \multicolumn{5}{|l|}{ Growth at: } \\
\hline $10{ }^{\circ} \mathrm{C}$ & + & - & - & - \\
\hline $40{ }^{\circ} \mathrm{C}$ & - & - & + & - \\
\hline Oxidase & + & + & + & - \\
\hline \multicolumn{5}{|l|}{ Hydrolysis of: } \\
\hline Agar & + & + & - & - \\
\hline Casein & - & + & + & + \\
\hline Gelatin & - & + & + & $\mathrm{w}$ \\
\hline Starch & + & + & - & + \\
\hline Tyrosine & - & + & + & + \\
\hline \multicolumn{5}{|l|}{ Utilization of: } \\
\hline Cellobiose & + & + & - & + \\
\hline D-Fructose & + & - & - & - \\
\hline D-Mannose & - & $\mathrm{w}$ & - & - \\
\hline D-Xylose & + & + & - & - \\
\hline Sucrose & + & - & - & - \\
\hline Acetate & - & - & - & + \\
\hline Pyruvate & - & + & - & + \\
\hline Salicin & + & + & - & - \\
\hline \multicolumn{5}{|l|}{ Enzyme activity (API ZYM) } \\
\hline Esterase (C4) & - & + & + & + \\
\hline Esterase lipase (C8) & - & + & - & + \\
\hline Acid phosphatase & + & - & + & - \\
\hline$N$-Acetyl- $\beta$-glucosaminidase & - & + & - & - \\
\hline \multicolumn{5}{|l|}{ Susceptibility to antibiotics } \\
\hline Ampicillin & + & - & - & - \\
\hline Cephalothin & - & + & + & + \\
\hline Kanamycin & + & - & + & $\mathrm{w}$ \\
\hline Oleandomycin & - & + & + & + \\
\hline Tetracycline & - & - & + & - \\
\hline DNA G $+\mathrm{C}$ content $(\mathrm{mol} \%)$ & 44.2 & 41.0 & 42.0 & 39.3 \\
\hline
\end{tabular}




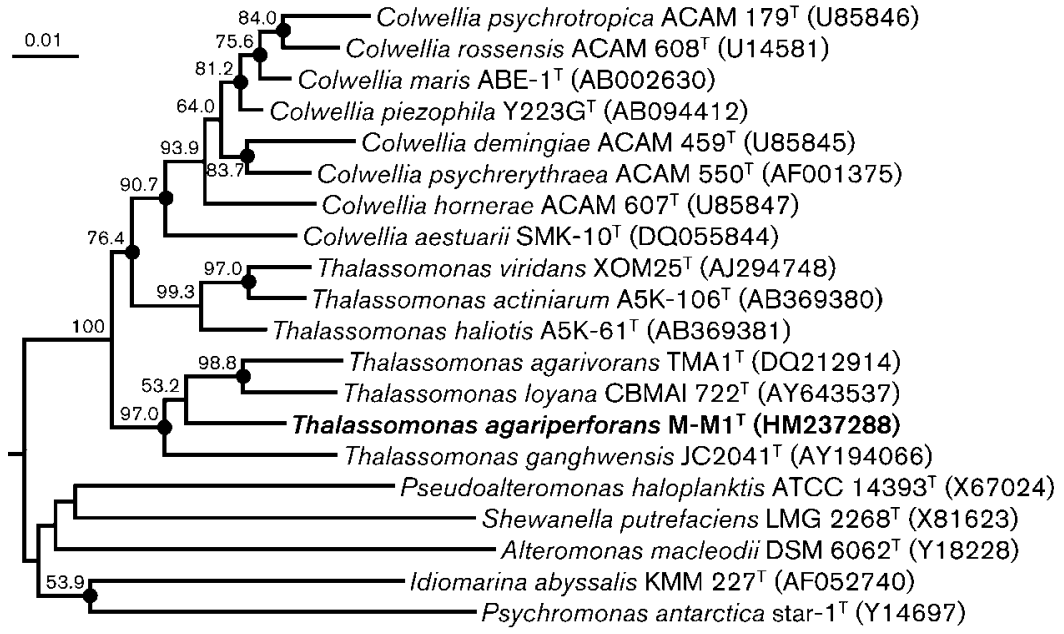

Fig. 1. Neighbour-joining phylogenetic tree based on 16S rRNA gene sequences showing the positions of strain $\mathrm{M}-\mathrm{M} 1^{\top}$, species of the genus Thalassomonas and some other related taxa. Bootstrap values (expressed as percentages of 1000 replications) $>50 \%$ are shown at branching points. Filled circles indicate that the corresponding nodes were also recovered in trees generated with the maximum-likelihood and maximum-parsimony algorithms. Pseudomonas aeruginosa DSM 50071 ${ }^{\top}$ (GenBank accession number, X06684) was used as an outgroup (not shown). Bar, 0.01 substitutions per nucleotide position. column. For cellular fatty acid analysis, cell mass of strain M$\mathrm{M}^{\mathrm{T}}$, T. agarivorans $\mathrm{JCM} 13379^{\mathrm{T}}$, T. loyana $\mathrm{LMG} 22536^{\mathrm{T}}$ and T. ganghwensis KCTC $12041^{\mathrm{T}}$ was harvested from MA plates after cultivation for 5 days at $30{ }^{\circ} \mathrm{C}$. The fatty acids were extracted and fatty acid methyl esters were prepared according to the standard protocol of the MIDI/Hewlett Packard Microbial Identification System (Sasser, 1990). The DNA G + C content was determined using the method of Tamaoka \& Komagata (1984) with the modification that DNA was hydrolysed using nuclease P1 (Sigma) and the resultant nucleotides were analysed by reversed-phase HPLC.

Morphological, cultural, physiological and biochemical characteristics of strain $\mathrm{M}-\mathrm{M} 1^{\mathrm{T}}$ are given in the species description (see below) and in Table 1. The almost complete 16S rRNA gene sequence of strain $\mathrm{M}-\mathrm{M} 1^{\mathrm{T}}$ determined in this study comprised $1465 \mathrm{nt}$, representing approximately $96 \%$ of the Escherichia coli $16 \mathrm{~S}$ rRNA gene sequence. In the phylogenetic tree based on the neighbour-joining algorithm, strain $\mathrm{M}-\mathrm{M} 1^{\mathrm{T}}$ fell within the clade comprising species of the genus Thalassomonas, forming a coherent cluster with $T$. agarivorans $\mathrm{TMA}^{\mathrm{T}}$, T. loyana CBMAI $722^{\mathrm{T}}$ and T. ganghwensis JC2041 ${ }^{\mathrm{T}}$ (Fig. 1). Strain M-M1 ${ }^{\mathrm{T}}$ exhibited $16 \mathrm{~S}$ rRNA gene sequence similarity values of $96.4,96.0$ and $94.9 \%$ with the type strains of $T$. agarivorans, $T$. loyana and $T$. ganghwensis, respectively, and 94.7-95.2\% with the other species of the genus Thalassomonas. The predominant isoprenoid quinone detected in strain $\mathrm{M}-\mathrm{M}^{\mathrm{T}}{ }^{\mathrm{T}}$ was ubiquinone-8 (Q-8), at a peak area ratio of approximately $94 \%$, in line with other species of the genus Thalassomonas (Yi et al., 2004; Hosoya et al., 2009). The cellular fatty acid profile of strain $\mathrm{M}-\mathrm{M} 1^{\mathrm{T}}$ is shown in Table 2, together with those of $T$. agarivorans JCM $13379^{\mathrm{T}}$, T. loyana LMG $22536^{\mathrm{T}}$ and $T$. ganghwensis KCTC $12041^{\mathrm{T}}$ also analysed in this study. Strain $\mathrm{M}-\mathrm{M} 1^{\mathrm{T}}$ contained large amounts of straight-chain and unsaturated fatty acids; the major components $(>10 \%$ of total fatty acids) were summed feature $3\left(\mathrm{C}_{16: 1} \omega 7 c\right.$ and/or iso- $\left.\mathrm{C}_{15: 0} 2-\mathrm{OH}\right), \mathrm{C}_{16: 0}$ and $\mathrm{C}_{18: 1} \omega 7 c$. The fatty acid patterns of the four strains were similar, but there were also differences in the proportions of some fatty acids (Table 2). The DNA $\mathrm{G}+\mathrm{C}$ content of strain $\mathrm{M}-\mathrm{M1}^{\mathrm{T}}$ was $44.2 \mathrm{~mol} \%$. The results obtained from chemotaxonomic analyses, showing properties that are shared by species of the genus Thalassomonas, were in agreement with the result of the phylogenetic analysis, i.e. that strain $\mathrm{M}-\mathrm{M1}^{\mathrm{T}}$ is a member of the genus Thalassomonas ( $\mathrm{Yi}$ et al., 2004; Jean et al., 2006; Thompson et al., 2006).

Strain $\mathrm{M}-\mathrm{M} 1^{\mathrm{T}}$ could be differentiated from T. agarivorans $\mathrm{TMAl}^{\mathrm{T}}$, T. loyana CBMAI $722^{\mathrm{T}}$ and $T$. ganghwensis JC2041 $1^{\mathrm{T}}$ by differences in several phenotypic characteristics, including hydrolysis of casein, gelatin and tyrosine, utilization of D-fructose and sucrose, activity of esterase (C4) and susceptibility to ampicillin, oleandomycin and cephalothin as shown in Table 1. Therefore, on the basis of the phylogenetic data and differential phenotypic properties, strain $\mathrm{M}-\mathrm{M} 1^{\mathrm{T}}$ is considered to represent a novel species of the genus Thalassomonas, for which the name Thalassomonas agariperforans sp. nov. is proposed.

\section{Description of Thalassomonas agariperforans sp. nov.}

Thalassomonas agariperforans [a.ga.ri.per.fo'rans. Malayan n. agar agar; N.L. n. agarum agar (algal polysaccharide); L. part. adj. perforans perforating, making holes; N.L. part. adj. agariperforans making holes in agar].

Cells are Gram-staining-negative, aerobic and rod-shaped, $0.5-0.8 \mu \mathrm{m}$ in diameter and 1.5-3.0 $\mu \mathrm{m}$ in length. Motile by means of a single polar flagellum. Colonies on MA are circular, yellowish-white, opaque and sunken into the agar. Anaerobic growth occurs on MA and on MA supplemented with nitrate. Optimal growth temperature is $30{ }^{\circ} \mathrm{C}$; growth occurs at 4 and $37^{\circ} \mathrm{C}$, but not at $40{ }^{\circ} \mathrm{C}$. Optimal pH for growth is between 7.0 and 8.0; growth occurs at $\mathrm{pH} 5.5$, but not at $\mathrm{pH}$ 5.0. Growth occurs in the presence of $0-6.0 \%(\mathrm{w} / \mathrm{v}) \mathrm{NaCl}$ with an optimum in the presence of approximately $2.0 \%(\mathrm{w} / \mathrm{v}) \mathrm{NaCl}$. $\mathrm{Mg}^{2+}$ ions are required for growth. Cellulose and xylan are hydrolysed. The predominant ubiquinone is Q-8. The major fatty acids ( $>10 \%$ of total fatty acids) are $\mathrm{C}_{16: 1} \omega 7 c$ and/or iso- $\mathrm{C}_{15: 0} 2-\mathrm{OH}, \mathrm{C}_{16: 0}$ and $\mathrm{C}_{18: 1} \omega 7 c$. The DNA G $+\mathrm{C}$ content is $44.2 \mathrm{~mol} \%$ (determined by HPLC). Other phenotypic characteristics are given in Table 1. 
Table 2. Cellular fatty acid compositions (\%) of strain $M-M 1^{\top}$ and the type strains of phylogenetically related species of the genus Thalassomonas

Strains: 1 , Thalassomonas agariperforans sp. nov. $\mathrm{M}-\mathrm{M1}^{\mathrm{T}} ; 2$, T. agarivorans JCM $13379^{\mathrm{T}}$; 3, T. ganghwensis KCTC $12041^{\mathrm{T}}$; 4, T. loyana LMG $22536^{\mathrm{T}}$. All data from this study. Fatty acids that represented $<1.0 \%$ in all strains were omitted. - , Not detected.

\begin{tabular}{|c|c|c|c|c|}
\hline Fatty acid & 1 & 2 & 3 & 4 \\
\hline \multicolumn{5}{|l|}{ Straight-chain } \\
\hline $\mathrm{C}_{10: 0}$ & 0.7 & 1.3 & 3.5 & - \\
\hline $\mathrm{C}_{11: 0}$ & - & 1.6 & 0.1 & 0.2 \\
\hline $\mathrm{C}_{12: 0}$ & 1.6 & 6.4 & 0.3 & 2.8 \\
\hline $\mathrm{C}_{13: 0}$ & - & 5.3 & - & 0.8 \\
\hline $\mathrm{C}_{14: 0}$ & 1.6 & 4.2 & 0.9 & 9.7 \\
\hline $\mathrm{C}_{15: 0}$ & 0.8 & 6.1 & 1.2 & 2.6 \\
\hline $\mathrm{C}_{16: 0}$ & 30.9 & 19.5 & 19.5 & 9.4 \\
\hline $\mathrm{C}_{17: 0}$ & 0.8 & 6.8 & 1.4 & 0.5 \\
\hline $\mathrm{C}_{18: 0}$ & 0.5 & 1.1 & 1.0 & 0.8 \\
\hline \multicolumn{5}{|l|}{ Branched } \\
\hline iso- $\mathrm{C}_{13: 0}$ & - & 1.4 & - & - \\
\hline iso- $\mathrm{C}_{14: 0}$ & - & 1.4 & 0.2 & 0.4 \\
\hline iso- $\mathrm{C}_{16: 0}$ & - & 0.7 & 2.8 & - \\
\hline \multicolumn{5}{|l|}{ Unsaturated } \\
\hline $\mathrm{C}_{15: 1} \omega 8 c$ & 0.5 & 2.0 & 1.8 & 2.1 \\
\hline $\mathrm{C}_{16: 1} \omega 9 c$ & - & 3.7 & 4.2 & 4.8 \\
\hline $\mathrm{C}_{17: 1} \omega 8 c$ & - & 9.2 & 7.2 & 10.6 \\
\hline $\mathrm{C}_{18: 1} \omega 7 c$ & 13.9 & 4.0 & 19.2 & 8.6 \\
\hline $\mathrm{C}_{18: 1} \omega 9 c$ & - & 2.2 & 1.7 & 2.9 \\
\hline \multicolumn{5}{|l|}{ Hydroxy } \\
\hline $\mathrm{C}_{10: 0} 3-\mathrm{OH}$ & 3.7 & - & 1.8 & - \\
\hline $\mathrm{C}_{11: 0} 3-\mathrm{OH}$ & - & 0.6 & 1.6 & 2.2 \\
\hline $\mathrm{C}_{12: 0} 3-\mathrm{OH}$ & 0.7 & 2.2 & 2.5 & 7.1 \\
\hline $\mathrm{C}_{12: 1} 3-\mathrm{OH}$ & 4.6 & - & - & - \\
\hline \multicolumn{5}{|c|}{ Summed features ${ }^{\star}$} \\
\hline 1 & - & 1.9 & - & 0.6 \\
\hline 2 & - & 2.5 & - & 1.1 \\
\hline 3 & 38.9 & 13.1 & 22.6 & 27.2 \\
\hline \multicolumn{5}{|l|}{ Unknown $\dagger$} \\
\hline ECL 11.799 & - & 0.2 & 0.3 & 1.9 \\
\hline
\end{tabular}

${ }^{*}$ Summed features represent groups of two or three fatty acids that could not be separated by GLC with the MIDI system. Summed feature 1 contained iso- $\mathrm{C}_{15: 1}$ and/or $\mathrm{C}_{13: 0} 3-\mathrm{OH}$; summed feature 2 contained iso- $\mathrm{C}_{16: 1}$ I and/or $\mathrm{C}_{14: 0} 3-\mathrm{OH}$; summed feature 3 contained $\mathrm{C}_{16: 1} \omega 7 c$ and/or iso- $\mathrm{C}_{15: 0} 2-\mathrm{OH}$.

$\dagger$ Equivalent chain-length.

The type strain, $\mathrm{M}-\mathrm{M} 1^{\mathrm{T}}$ (=KCTC $23343^{\mathrm{T}}=\mathrm{CCUG}$ $60020^{\mathrm{T}}$ ), was isolated from marine sand of Geoje island in the South Sea, Korea.

\section{Acknowledgements}

This work was supported by the 21C Frontier Program of Microbial Genomics and Applications (grant 11-2008-00-002-00) from the Ministry of Education, Science and Technology (MEST) of the Republic of Korea.

\section{References}

Baumann, P. \& Baumann, L. (1981). The marine Gram-negative eubacteria: genera Photobacterium, Beneckea, Alteromonas, Pseudomonas, and Alcaligenes. In The Prokaryotes, vol. 2, pp. 1302-1331. Edited by M. P. Starr, H. Stolp, H. G. Trüper, A. Balows \& H. G. Schlegel. Berlin: Springer.

Bowman, J. P. \& McMeekin, T. A. (2005). Order X. Alteromonadales ord. nov. In Bergey's Manual of Systematic Bacteriology, 2nd edn, vol. 2, part B, pp. 443. Edited by D. J. Brenner, N. R. Krieg, J. T. Staley \& G. M. Garrity. New York: Springer.

Bruns, A., Rohde, M. \& Berthe-Corti, L. (2001). Muricauda ruestringensis gen. nov., sp. nov., a facultatively anaerobic, appendaged bacterium from German North Sea intertidal sediment. Int J Syst Evol Microbiol 51, 1997-2006.

Cohen-Bazire, G., Sistrom, W. R. \& Stanier, R. Y. (1957). Kinetic studies of pigment synthesis by nonsulfur purple bacteria. J Cell Comp Physiol 49, 25-68.

Cowan, S. T. \& Steel, K. J. (1965). Manual for the Identification of Medical Bacteria. London: Cambridge University Press.

Hosoya, S., Adachi, K. \& Kasai, H. (2009). Thalassomonas actiniarum sp. nov. and Thalassomonas haliotis sp. nov., isolated from marine animals. Int J Syst Evol Microbiol 59, 686-690.

Jean, W. D., Shieh, W. Y. \& Liu, T. Y. (2006). Thalassomonas agarivorans sp. nov., a marine agarolytic bacterium isolated from shallow coastal water of An-Ping Harbour, Taiwan, and emended description of the genus Thalassomonas. Int J Syst Evol Microbiol 56, 1245-1250.

Komagata, K. \& Suzuki, K. (1987). Lipid and cell wall analysis in bacterial systematics. Methods Microbiol 19, 161-207.

Lanyi, B. (1987). Classical and rapid identification methods for medically important bacteria. Methods Microbiol 19, 1-67.

Macián, M. C., Ludwig, W., Schleifer, K. H., Garay, E. \& Pujalte, M. J. (2001). Thalassomonas viridans gen. nov., sp. nov., a novel marine $\gamma$ proteobacterium. Int J Syst Evol Microbiol 51, 1283-1289.

Sasser, M. (1990). Identification of bacteria by gas chromatography of cellular fatty acids, MIDI Technical Note 101. Newark, DE: MIDI Inc.

Staley, J. T. (1968). Prosthecomicrobium and Ancalomicrobium: new prosthecate freshwater bacteria. J Bacteriol 95, 1921-1942.

Tamaoka, J. \& Komagata, K. (1984). Determination of DNA base composition by reverse-phase high-performance liquid chromatography. FEMS Microbiol Lett 25, 125-128.

Teather, R. M. \& Wood, P. J. (1982). Use of Congo red-polysaccharide interactions in enumeration and characterization of cellulolytic bacteria from the bovine rumen. Appl Environ Microbiol 43, 777-780.

Thompson, F. L., Barash, Y., Sawabe, T., Sharon, G., Swings, J. \& Rosenberg, E. (2006). Thalassomonas loyana sp. nov., a causative agent of the white plague-like disease of corals on the Eilat coral reef. Int J Syst Evol Microbiol 56, 365-368.

Yi, H., Bae, K. S. \& Chun, J. (2004). Thalassomonas ganghwensis sp. nov., isolated from tidal flat sediment. Int J Syst Evol Microbiol 54, 377-380.

Yoon, J.-H., Kim, H., Kim, S.-B., Kim, H.-J., Kim, W. Y., Lee, S. T., Goodfellow, M. \& Park, Y.-H. (1996). Identification of Saccharomonospora strains by the use of genomic DNA fragments and rRNA gene probes. Int J Syst Bacteriol 46, 502-505.

Yoon, J.-H., Lee, S. T. \& Park, Y.-H. (1998). Inter- and intraspecific phylogenetic analysis of the genus Nocardioides and related taxa based on 16S rDNA sequences. Int J Syst Bacteriol 48, 187-194.

Yoon, J.-H., Kim, I.-G., Shin, D.-Y., Kang, K. H. \& Park, Y.-H. (2003). Microbulbifer salipaludis sp. nov., a moderate halophile isolated from a Korean salt marsh. Int J Syst Evol Microbiol 53, 53-57. 